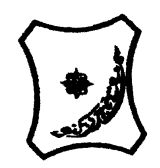

Bayero Journal of Pure and Applied Sciences, 14(1):167 - 176

Received: January, 2021

Accepted: April, 2021

ISSN 2006 - 6996

\title{
ASSESSING THE POTENTIAL of Khayasenegalensis IN PHYTOREMEDIATION OF HEAVY METALS UNDER BOREHOLE WATER AND TANNERY EFFLUENT IRRIGATION
}

\author{
${ }^{*}{ }^{1}$ Zakari, A. and ${ }^{1}$ Audu, A. A. \\ ${ }^{1}$ Department of Pure and Industrial Chemistry, Bayero University, Kano, Nigeria. \\ *Corresponding Author: azakari.chm@buk.edu.ng
}

ABSTRACT

Khayasenegalensis was planted on soil irrigated with tannery effluent and borehole water for duration of three months. Plant samples were collected after harvest and soil samples were collected before planting and after harvesting. Atomic Absorption Spectroscopy (AAS) was used to determine the concentration of heavy metals in the planting media and plant tissues. The aim was to establish the phytoremediation potential of Khayasenegalensis under these conditions. After harvesting, a noticeable decrease in the concentrations of $\mathrm{Cd}, \mathrm{Cr}, \mathrm{Cu} \mathrm{Ni}, \mathrm{Pb}$ and $\mathrm{Zn}$ in the media was observed from the initial values. The highest levels of Cd $(5.53 \pm 0.56 \mathrm{mg} / \mathrm{kg}), \mathrm{Cr}(13.99 \pm$ $0.82 \mathrm{mg} / \mathrm{kg}), P b(10.61 \pm 0.57 \mathrm{mg} / \mathrm{kg})$, Ni $(8.33 \pm 2.78 \mathrm{mg} / \mathrm{kg})$ and $\mathrm{Zn}(25.72 \pm 0.00 \mathrm{mg} / \mathrm{kg})$ accumulation were found in the roots, whereas the highest $\mathrm{Cu}((7.29 \pm 1.80 \mathrm{mg} / \mathrm{kg})$ concentrations was observed in the shoot.. The roots of Khayasenegalensis were found to be suitable for the phytostabilization heavy metals in both the tannery effluent and borehole water irrigated media..In addition, $\mathrm{Cd}, \mathrm{Cr}, \mathrm{Cu}$, Ni and Pb mainly accumulated in the Khayasenegalensisroots. The results of translocation factors (TF) and bioconcentration factors (BCF) of Khayasenegalensis for heavy metals revealed that Khayasenegalensis is an excluder plant for $\mathrm{Cd}, \mathrm{Cr}, \mathrm{Pb}, \mathrm{Ni}$ and $\mathrm{Zn}$ and a potential accumulator plant for $\mathrm{Cu}$ serving as an ideal remediation plant for this metal. Furthermore, the increasing heavy metal contents in soil that have been irrigated with tannery effluent resulted in the accumulation of these metals in Khayasenegalensis. Key words: Heavy metals, Khayasenegalensis, phytoremediation, AAS, Tannery effluent.

\section{INTRODUCTION}

The widespread accumulation of heavy metals in the environment is becoming an increasingly main concern worldwide as a result of the pollution of the ecosystem that comes with it ( $\mathrm{Si}$ et al., 2021); Li et al., 2021;Zhang et al., 2020; He et al., 2020;Steliga \& Kluk, 2020).One of this environmental pollution is soil contamination by heavy metals due to land degradation caused by synthetic substances or Anthropogenic activities (Ibrahim and El, 2020). These heavy metals are those element that have relatively high atomic and mass number greater than 20 and $5 \mathrm{~g} / \mathrm{cm}^{3}$ respectively (Godwin and Oluwagbemiga, 2020).They are present in industrial effluents and municipal waste both in liquid and solid state in excessive concentrations posing very damaging effects to both fauna and flora(Amir et al., 2020). Irrigation by sewage water and industrial effluents has been cited as a major reason for accumulation of heavy metals in the plants (Gupta et al., 2008; Ullah et al., 2021). The conventional methods of tackling heavy metal contamination from polluted soil, includes chemical oxidation, soil vapor extraction, solidification, soil flushing, and electrokinetics separation most times do not yield expected results or are not encouraging due to the fact that it is an expensive process (Elshamy et al., 2019; Eid et al., 2020). Phytoremediation, a promising and cost effective approach is a widely accepted approach of confronting this age old problem due to its economic feasibility and eco-friendliness(Ravi et al., 2020). Phytoremediation of contaminated soils is defined as "use of plants or their rhizosphere to remove contaminants through harvestable sections including stems and leaves (phytoextraction) or the control and immobilization of contaminants in roots (phytostabilization)"(Yang et al., 2020). In Phytoremediation, plants are used to remove pollutants from environmental media. Plants act as bioreactors, as their roots show unique and selective pollutant uptake capabilities, and the shoot is a site for translocation, bioaccumulation, and contaminant degradation (Madanan et al., 2021). 
BAJOPAS Volume 14 Number 1,June, 2021

In spite of the fact that traditional phytoremediation by using native plants to alleviate soil contamination seems a viable approach to tackle pollution of soil by heavy metals, it has not been applied successfully as a result of a number of limitations. The use of native plants having the ability to accumulate trace metals for phytoremediation has an important ecological aspect since these plants are more efficient in terms of survival under environmental stress conditions than introduced plants(Eid et al., 2020). Khayasenegalensis (Family: Meliaceae) was selected for this study. It is a Juss (called madaciin Hausa speaking communities of Nigeria and mahogany in English) (Tauheed et al., 2020). Studies are available that show absorption of heavy metals from metal contaminated soils by this plant (Olajuyigbe and Aruwajoye, 2014) and its quantification of some phytochemicals and minerals found in its aqueous stem bark extract. Other studies have been conducted on the accumulation of heavy metals in plant tissues irrigated with wastewater (Wise and Mokokwe, 2020)
Current knowledge regarding the potential phytoremediation of soils treated with tannery waste water (effluent) by Khayasenegalensisis limited. Therefore, this study was designed to elucidate the potential of Khayasenegalensis to clean toxic heavy metals in soils treated with effluent waste water from the tannery industry in Challawa Industrial Estate, Kano, Nigeria. A Picture of Khayasenegalensis under experimental set up (Plate 2.

\section{MATERIALS AND METHODS \\ The study area}

The current study was carried out in the in a screen house in botanical garden of Plant Biology department of Bayero University Kano. The area is located between latitudes $11^{\circ} 58^{\prime} 3.79^{\prime \prime}$ and $8^{\circ} 24^{\prime} 27.08^{\prime \prime}$ in Gwale local government of Kano state. The global positioning system (GPS) was used in recording the coordinates Geographical Information System (GIS) was used to locate the map of the study area as shown below (Plate 1 ).

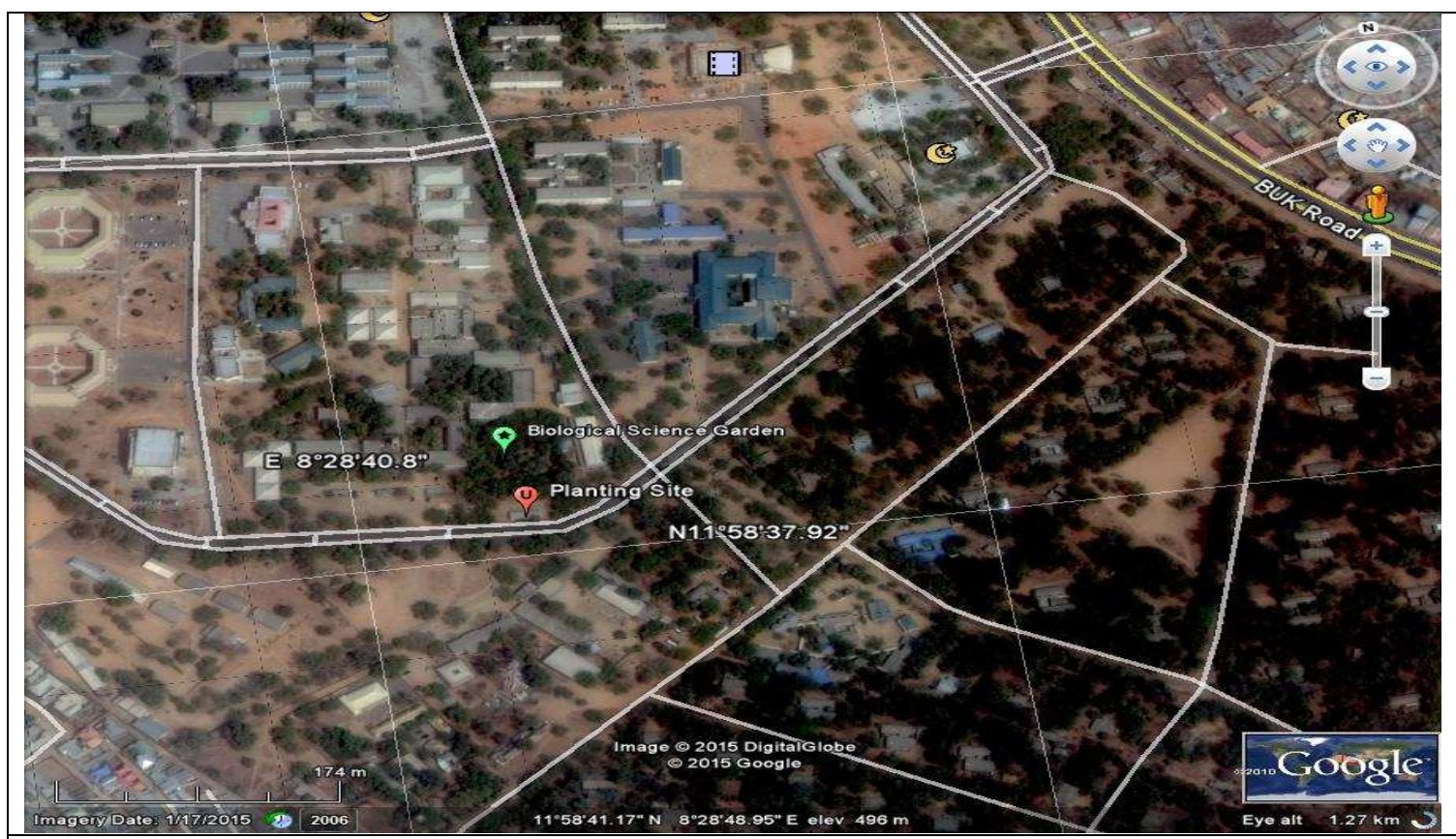

Plate 1: Google Map showing Planting Location in the Screen House of thePlant Biology Department, Bayero University, Kano, Nigeria.

\section{Soil sampling}

Soil sample for this research was collected from Challawa Industrial area of Kano, Kano state, Nigeria at a depth of $20 \mathrm{~cm}$. The surface soil layer to a depth of $0-20 \mathrm{~cm}$ (ploughing layer) was sampled with a stainless steel auger and the soil sample was transferred to a labelled bag (Cuske et al., 2016).

\section{Soil preparation for pot experiment}

Seeds of the six plant species were planted in pots filled with $5 \mathrm{~kg}$ of soil type intended for planting (i.e. Soil from locations at Challawa Industrial Estate) and control soil from Langel village which is a non-industrial farm settlement and irrigated for up to 90 days in a screen house in botanical garden of Plant Biology Department 
BAJOPAS Volume 14 Number 1,June, 2021

of Bayero University, Kano. Seeds were irrigated with water up to field capacity of the soil daily or every third day with effluent to maintain optimum water conditions. The plants were grown for a period of three months (90days).

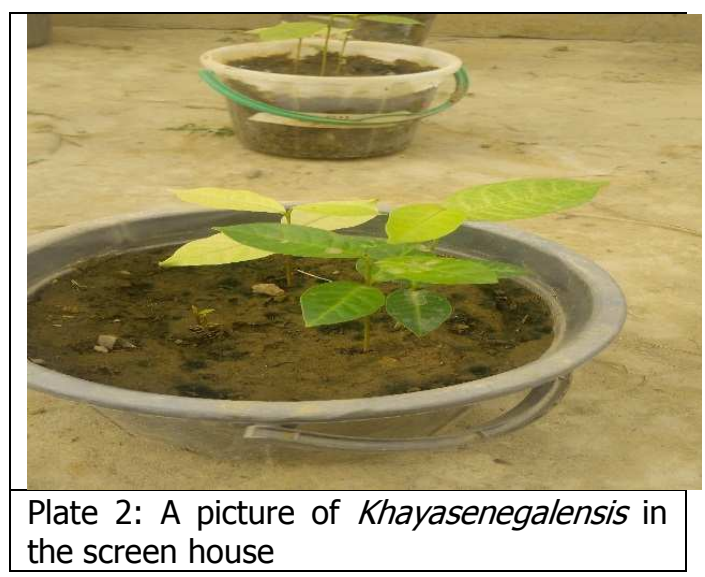

\section{Collection and preparation of Industrial effluent}

Tannery industrial effluents were collected from discharge points of the various tannery industries in Challawa area. The collected samples of tannery waste water effluents were mixed together and then used as irrigation water.

\section{Digestion of soil samples}

$1 \mathrm{~g}$ of the soil sample from Yandanko, at Challawa was mixed with $20 \mathrm{~cm}^{3}$ of nitric acid $\left(\mathrm{HNO}_{3}\right)\left(70 \% \mathrm{w} / \mathrm{v}, \mathrm{S} . \mathrm{G} 1.42 \mathrm{~g} / \mathrm{cm}^{3}\right)$ and allowed to stand for 1 hour. $15 \mathrm{~cm}^{3}$ of perchloric acid $\left(\mathrm{HClO}_{4}\right)\left(70 \% \mathrm{w} / \mathrm{v}, \mathrm{S} . \mathrm{G} 1.67 \mathrm{~g} / \mathrm{cm}^{3}\right)$ was then added and the mixture was placed in a sand bath and heated at $55^{\circ} \mathrm{C}$ until dense white fumes were observed. It was allowed to cool and filtered into the $100 \mathrm{~cm}^{3}$ volumetric flask and made to the mark. The resulting solution was analysed for metal concentrations using Atomic Absorption Spectrophotometer Buck scientific, Model-210VGP (Tanee and Amadi, 2016).

\section{Plant Tissue Analysis}

Before the analyses root and shoot samples were thoroughly washed using distilled water to remove all adhering soil particles. Samples were then oven dried to constant weights at $105^{\circ} \mathrm{C}$. Each dried sample was ground to powder and 0.5 gram of each sample was used for analysis. These samples were placed in a crucible and transferred to the muffle furnace and ashed at $550^{\circ} \mathrm{C}$. The ash is then dissolved in $10 \mathrm{ml} 0.1 \mathrm{M}$ nitric acid, filtered and made up to the $100 \mathrm{~cm}^{3}$ mark and analysed for metal content using Atomic Absorption spectrophotometer (Inuwa and Mohammed, 2018).
After 90 days the plant samples from each pot was collected and washed thoroughly with distilled water so that no soil particles remained. Plate 2 shows a picture of Khayasenegalensis in the screen house.

\section{Statistical analysis}

All data gathered were analyzed statistically using analysis of variance (ANOVA). When significant differences were detected between treatments, Tukey test (at $\mathrm{P}<0.05$ ) was calculated for each parameter and all graphs were plotted by employing Microsoft Excel (Mohanty \& Patra, 2020).

\subsection{RESULTS AND DISCUSSION}

3.1 Heavy Metal Concentrations in Plant Tissues and Soil Media before Planting and after Harvesting

The concentrations of $\mathrm{Cd}, \mathrm{Cr}, \mathrm{Cu}, \mathrm{Ni}, \mathrm{Pb}$ and $\mathrm{Zn}$ in plant tissues (shoots and roots) and soil media before planting and after harvesting for $K$. senegalensis are as shown in fig 2-6. The following description were adopted in labelling the tissues of $K$. senegalensis and the growth medium where they were planted viz; the heavy metal concentration in the plant tissues are represented as effluent irrigated plant tissue are labeled EFKHST (shoot) and EFKHRT (root) and EFKHS (for effluent irrigated soil medium) The borehole water irrigated plant tissue and soil are labeled; WKHST (for shoot), WKHRT (for root), WKHS (for borehole water irrigated soil medium) and control.

Fig. 1 shows the uptake of Cadmiumby the tissues of $K$. senegalensis in the respective growth media. The concentrations of $\mathrm{Cd}$ after 3 months in the tissues were $3.58 \pm 0.56 \mathrm{mg} / \mathrm{kg}$, $5.53 \pm 0.56 \mathrm{mg} / \mathrm{kg}, 2.93 \pm 0.98 \mathrm{mg} / \mathrm{kg}, 3.90 \pm 0.00$ $\mathrm{mg} / \mathrm{kg}$, in EFKHST (shoot), EFKHRT (root), WKHST (shoot), WKHRT (root) respectively and the control plant values gives the lowest concentration of $1.30 \pm 0.56 \mathrm{mg} / \mathrm{kg}$ (shoot) and $1.63 \pm 0.56 \mathrm{mg} / \mathrm{kg}$ (root). 
BAJOPAS Volume 14 Number 1,June, 2021

The initial Cd level of the growth media was $12.85 \mathrm{mg} / \mathrm{kgin}$ both EFKHS and WKHS and 9.43 $\mathrm{mg} / \mathrm{kg}$ in control before planting. However, after harvesting, the $\mathrm{Cd}$ level decreases in the residual soil sample after remediation with the plant to $4.07,2.93$, and $6.02 \mathrm{mg} / \mathrm{kg}$ in EFKHS, WKHS and control respectively as illustrated by Fig. 1.This shows an appreciable proportion of cadmium was removed from the soil which could be traced to uptake of this metal by the tissues of K. senegalensis.

As for the tissues, $K$. senegalensis took up more concentration of $\mathrm{Cd}$ in the roots compared to concentrations in the shoots. The total uptake of $\mathrm{Cd}$ by the plant with respect to the initial metal in the soil media is $8.13 \mathrm{mg} / \mathrm{kg} 6.83 \mathrm{mg} / \mathrm{kg}$, and $2.93 \mathrm{mg} / \mathrm{kg}$ as represented by the soil media of EFKHS, WKHS and the control respectively (Fig 1).The highest $\mathrm{Cd}$ accumulation $(5.53 \pm 0.56 \mathrm{mg} / \mathrm{kg})$ was observed in the root of the $K$. senegalensis planted in the EFKHS growth media while the lowest shoot accumulation of $1.95 \pm 0.56 \mathrm{mg} / \mathrm{kg}$ was observed in the control (Fig 1). As for the root, the highest $\mathrm{Cd}$ concentration of $4.23 \pm 0.33 \mathrm{mg} / \mathrm{kg}$ was observed in growth medium EFKHS represented by EFKHRT. The lowest root accumulation of $\mathrm{Cd}$ $(1.63 \pm 0.56 \mathrm{mg} / \mathrm{kg})$ was detected in the control. One way Anova shows that there is significant difference between the Cd levels in the shoots of the Khayasenegalensis obtained from irrigation with tannery effluent, borehole water and control at $\mathrm{P}<$ 0.05. The Post Hoc Tukey test however, revealed that the $\mathrm{Cd}$ levels in the root of Khayasenegalensis from the tannery effluent irrigated medium is not significantly higher than those obtained from the borehole water irrigated soil but significantly higher than control. Also, the root levels of Cd obtained from irrigation with borehole water is significantly higher than control. This results however differs with the findings of Ali et al., 2013 for the same plant which had higher Cd levels in the leaf tissues than the root(Ali et al., 2013).The deposition of Cd in plants in $\mathrm{Cd}$ polluted soil poses serious problems to the health of animals and humans due to its high mobility in contaminated soils(Ullah et al., 2021).

Fig. 2 illustrates the uptake of Chromium (Cr) by the tissues of $K$. senegalensis in the respective growth media. The concentrations of $\mathrm{Cr}$ after 3 months in the tissues were $11.65 \pm 1.65 \mathrm{mg} / \mathrm{kg}$, $13.99 \pm \quad 0.82 \mathrm{mg} / \mathrm{kg}$ ， $7.41 \pm 2.47 \mathrm{mg} / \mathrm{kg}$ ， $10.50 \pm 1.65 \mathrm{mg} / \mathrm{kg}$, and in EFKHST (shoot), EFKHRT (root), WKHST (shoot), WKHRT (root), respectively and the control plant values gives the lowest concentration of $2.47 \pm 0.00 \mathrm{mg} / \mathrm{kg}$ (shoot) and $2.47 \pm 0.00 \mathrm{mg} / \mathrm{kg}$ (root). The initial $\mathrm{Cr}$ content of the soil media were $52.77 \mathrm{mg} / \mathrm{kg}$ in both EFKHS and WKHS and $8.33 \mathrm{mg} / \mathrm{kg}$ in control before planting. However, after harvesting, the
$\mathrm{Cr}$ level decreases in the residual soil sample after remediation with the plant to 24.69, 32.51 and $3.70 \mathrm{mg} / \mathrm{kg}$ in EFKHS, WKHS and control respectively. The results indicate that in the effluent irrigated media, $K$. senegalensis mopped up more amounts of $\mathrm{Cr}$ in the roots compared to concentrations in the shoots. With respect to the borehole irrigated media a similar trend of more PTE accumulation in the roots were observed. The results indicate that $K$. senegalensis mopped up more amounts of $\mathrm{Cr}$ in the roots compared to concentrations in the shoots (Fig 2). This is in agreement with the findings of Muhammad et al., (2013) in a related research for the same plant. After 3months period, the total uptake of $\mathrm{Cr}$ by the plant with respect to the initial metal in the soil media is $25.51 \mathrm{mg} / \mathrm{kg}, 18.93 \mathrm{mg} / \mathrm{kg}$ and $4.94 \mathrm{mg} / \mathrm{kg}$ as represented by the soil media of EFKHS, WKHS and the control respectively (Fig 2). The highest $\mathrm{Cr}$ accumulation (13.99 $0.82 \mathrm{mg} / \mathrm{kg})$ was observed in the root of the $K$. senegalensis planted in the EFKHS growth media while the lowest root accumulation of $2.47 \pm 0.00 \mathrm{mg} / \mathrm{kg}$ was observed in the control (Fig 2).) Previous research reports on heavy metal accumulation by several terrestrial plants have also shown that roots have higher metal deposition than other parts of plant (Mohanty \& Patra, 2020). Also, in another study, Hyptissuaveolens L. roots showed high accumulation of $\mathrm{Cr}$ (Sivakumar, 2016). This is consistent with the findings of our study.

One way Anova shows that there is significant difference between the $\mathrm{Cr}$ levels in the roots of the Khayasenegalensis obtained from irrigation with tannery effluent, borehole water and control at P < 0.05.The Post Hoc Tukey test however, revealed that the $\mathrm{Cr}$ levels in the root of Khayasenegalensis from the tannery effluent irrigated medium is not significantly higher than those obtained from the borehole water irrigated soil but significantly higher than control. Also, the root levels of Cr obtained from irrigation with borehole water is significantly higher than control.

Fig. 3 illustrates the uptake of Copper (Cu)by the tissues of $K$. senegalensis in the respective growth media. The concentrations of $\mathrm{Cu}$ after 3 months in the tissues were $7.29 \pm 1.80 \mathrm{mg} / \mathrm{kg}$, $6.25 \pm 0.00 \mathrm{mg} / \mathrm{kg}, 6.25 \pm 0.00 \mathrm{mg} / \mathrm{kg}, 4.17 \pm 1.80$ $\mathrm{mg} / \mathrm{kg}$, in EFKHST (shoot), EFKHRT (root), WKHST (shoot), WKHRT (root) respectively and the control plant values gives the lowest concentration of $5.21 \pm 1.80 \mathrm{mg} / \mathrm{kg}$ (shoot) and $3.13 \pm 0.00 \mathrm{mg} / \mathrm{kg}$ (root). The initial Cu content of the growth media were $20.08 \mathrm{mg} / \mathrm{kg}$ in both EFKHS and WKHS and $15.71 \mathrm{mg} / \mathrm{kg}$ in control before planting. However, after harvesting, the $\mathrm{Cu}$ level decreases after remediation to 7.29, 
BAJOPAS Volume 14 Number 1,June, 2021

8.85, and6.25mg/kg in EFKHS, WKHS and control respectively as illustrated by Fig. 3.The results indicate that in the effluent irrigated media, uptake of $\mathrm{Cu}$ in the shoots of $K$. senegalensis was more pronounced compared to concentrations in the roots. A similar trend was observed in the borehole irrigated media. The total uptake of $\mathrm{Cu}$ by the plant with respect to the initial metal in the growth media is $13.54 \mathrm{mg} / \mathrm{kg}, 10.42 \mathrm{mg} / \mathrm{kg}$ and $8.33 \mathrm{mg} / \mathrm{kg}$ as represented by the growth media ofEFKHS, WKHS and the control respectively (Fig 3). The highest $\mathrm{Cu}$ accumulation $(7.29 \pm 1.80 \mathrm{mg} / \mathrm{kg}$ ) was observed in the shoot of the $K$. senegalensis planted in the EFKHS growth media while the lowest shoot accumulation of $5.21 \pm 1.80 \mathrm{mg} / \mathrm{kg}$ was observed in the control (Fig 3). One way Anova shows that there is significant difference between the $\mathrm{Cu}$ levels in the shoots of the Khayasenegalensis obtained from irrigation with tannery effluent, borehole water and control at $\mathrm{P}<$ 0.05.The Post Hoc Tukey test however, revealed that the $\mathrm{Cu}$ levels in the shoot of Khayasenegalensis obtained from the tannery effluent, borehole water irrigated media and control are not significantly different from each other. The present findings showed total $\mathrm{Cu}$ concentration in the shoots more than root $\mathrm{Cu}$ concentration in effluent treated medium than the water irrigated medium. This result agrees with the findings of (Yang et al., 2020) with another woody specie willow, Salix spp which accumulated high quantities of $\mathrm{Cu}$ in the shoots. A similar result observation was made with the findings of (Purakayastha et al., 2008) with another plant Brassica juncea which accumulated in high quantities of $\mathrm{Cu}$ in the shoots.

Fig. 4illustrates the uptake of Nickel (Ni)by the tissues of $K$. senegalensis in the respective growth media. The concentrations of $\mathrm{Ni}$ after 3 months in the tissues were $3.70 \pm 1.60 \mathrm{mg} / \mathrm{kg}$, $4.71 \pm 1.60 \mathrm{mg} / \mathrm{kg}$, $7.41 \pm 4.24 \mathrm{mg} / \mathrm{kg}$, $8.33 \pm 2.78 \mathrm{mg} / \mathrm{kg}$ in EFKHST (shoot), EFKHRT (root), WKHST (shoot) and WKHRT (root) respectively and the control plant values gives the lowest concentration of $3.70 \pm 1.60 \mathrm{mg} / \mathrm{kg}$ (shoot) and $6.48 \pm 1.60 \mathrm{mg} / \mathrm{kg}$ (root). The observed initial value of Nickel in EFKHS, WKHS and control were $39.69,39.69,17.46 \mathrm{mg} / \mathrm{kg}$ and only a residual amount of $28.70,23.61,7.41$ $\mathrm{mg} / \mathrm{kg}$ was detected in the soil media after remediation respectively as depicted by Fig. 4.The results indicate that in the effluent irrigated media, $K$. senegalensis took up more amounts of $\mathrm{Ni}$ in the roots compared to concentrations in the shoots. Similar observations were made in the borehole irrigated media. The results also showed that, at the end of 3months period, the total uptake of
$\mathrm{Ni}$ by the plant with respect to the initial metal in the growth media are $11.11 \mathrm{mg} / \mathrm{kg}, 15.74$ $\mathrm{mg} / \mathrm{kg}$, and $10.19 \mathrm{mg} / \mathrm{kg}$ as represented by the growth media of EFKHS, WKHS and the control respectively (Fig 5 ). The highest $\mathrm{Ni}$ accumulation $(8.33 \pm 0.00 \mathrm{mg} / \mathrm{kg})$ was observed in the root of the $K$. senegalensis planted in the WKHS soil media while the lowest root accumulation of $4.71 \pm 1.60 \mathrm{mg} / \mathrm{kg}$ was observed in EFKHS (Fig 4). One way Anova shows that there is significant difference between the $\mathrm{Ni}$ levels in the roots of the Khayasenegalensis obtained from irrigation with tannery effluent, borehole water and control at $\mathrm{P}<$ 0.05. The Post Hoc Tukey test however, revealed that the $\mathrm{Ni}$ levels in the root of Khayasenegalensis obtained from the tannery effluent, borehole water irrigated media and control are not significantly different from each other. The present findings showed total $\mathrm{Ni}$ concentration in the roots more than shoot $\mathrm{Ni}$ concentration in effluent treated medium than the water irrigated medium. This results agrees with the findings of (Olajuyigbe and Aruwajoye, 2014)who reported high accumulation for the roots of the same plant.

Fig. 5 illustrates the uptake of Lead $(\mathrm{Pb})$ by the tissues of $K$. senegalensis in the respective growth media. The concentrations of $\mathrm{Pb}$ after 3 months in the tissues were $7.30 \pm 0.29 \mathrm{mg} / \mathrm{kg}$, $10.61 \pm 0.57 \mathrm{mg} / \mathrm{kg}, 2.32 \pm 0.29 \mathrm{mg} / \mathrm{kg}$ and $3.15 \pm 0.29 \mathrm{mg} / \mathrm{kg}$ in EFKHST (shoot), EFKHRT (root), WKHST (shoot), and WKHRT (root) respectively and the control plant values gives the lowest concentration of $0.50 \pm 0.00 \mathrm{mg} / \mathrm{kg}$ (shoot) and $1.33 \pm 0.29 \mathrm{mg} / \mathrm{kg}$ (root). Fig. 5 also shows the uptake of Lead where the initial value was $31.74 \mathrm{mg} / \mathrm{kg}$ in both EFKHS and WKHS and $7.93 \mathrm{mg} / \mathrm{kg}$ and control. However, decreases in the final level after harvest in $\mathrm{mg} / \mathrm{kg}$ were $12.02,17.16$ and 4.81 respectively. In Effluent irrigated media, $K$. senegalensis mopped up more amounts of $\mathrm{Pb}$ in the roots compared to concentrations in the shoots. A similar trend was observed in the borehole irrigated media. After harvesting, the total uptake of $\mathrm{Pb}$ by the plant with respect to the initial metal levels in the soil media are $17.91 \mathrm{mg} / \mathrm{kg}, 5.47 \mathrm{mg} / \mathrm{kg}$ and $1.82 \mathrm{mg} / \mathrm{kg}$ as represented by the growth media of EFKHS, WKHS and the control respectively (Fig 5). The highest $\mathrm{Pb}$ accumulation $(10.61 \pm 0.57 \mathrm{mg} / \mathrm{kg})$ was observed in the root of the $K$. senegalensis planted in the EFKHS growth medium while the lowest root accumulation of $1.33 \pm 0.29 \mathrm{mg} / \mathrm{kg}$ was observed in the control (Fig 5). One Way ANOVA shows that there is significant difference between the $\mathrm{Pb}$ levels in the shoots of the Khayasenegalensis obtained from irrigation with tannery effluent, borehole water and control at $P<0.05$. The Post Hoc Tukey test however, revealed that the $\mathrm{Pb}$ levels in the root of 
BAJOPAS Volume 14 Number 1,June, 2021

Khayasenegalensis from the tannery effluent irrigated medium is significantly higher than those obtained from the borehole water irrigated soil and control. Also, the root levels of $\mathrm{Pb}$ obtained from irrigation with borehole water is significantly higher than control. Overall, results show that $\mathrm{Pb}$ mostly accumulates in the roots. Our results agree with the findings of (Olajuyigbe and Aruwajoye, 2014 ; Ali et al., 2013 for the same plant and (Sharma et al., 2021) who reported high $\mathrm{Pb}$ concentrations in the roots of Eclipta alba (L).

Fig. 6 illustrates the uptake of Zinc (Zn)by the tissues of $K$. senegalensis in the respective growth media. The concentrations of $\mathrm{Zn}$ after 3 months in the tissues were $9.89 \pm 0.00 \mathrm{mg} / \mathrm{kg}$, $18.46 \pm 1.14 \mathrm{mg} / \mathrm{kg}, \quad 1.98 \pm 0.00 \mathrm{mg} / \mathrm{kg}$, and $11.87 \pm 0.00 \mathrm{mg} / \mathrm{kg}$, in EFKHST (shoot), EFKHRT (root), WKHST (shoot) and WKHRT (root) respectively and the control plant values gives the lowest concentration of $2.64 \pm 1.14 \mathrm{mg} / \mathrm{kg}$ (shoot) and $3.30 \pm 1.14 \mathrm{mg} / \mathrm{kg}$ (root).In the effluent irrigated media, $K$. senegalensis mopped up more amounts of $\mathrm{Zn}$ in the roots compared to concentrations in the shoots. Fig 6 also shows Zinc levels in the soil media where the observed initial value of Zincin both EFKHS and WKHS was $87.04 \mathrm{mg} / \mathrm{kg}$ where the control has a value of $35.09 \mathrm{mg} / \mathrm{kg}$. A residual amount of 57.70 , $71.22,28.68 \mathrm{mg} / \mathrm{kg}$ were detected in the growth media after harvest in EFKHS, WKHS and control respectively. After harvest, the total uptake of $\mathrm{Zn}$ by the plant with respect to the initial metal in the growth media is $28.35 \mathrm{mg} / \mathrm{kg}$, $13.85 \mathrm{mg} / \mathrm{kg}, 5.93 \mathrm{mg} / \mathrm{kg}$ as represented by the growth media of EFKHS, WKHS and the control respectively (Fig 6). The highest $\mathrm{Zn}$ accumulation $(18.46 \pm 1.14 \mathrm{mg} / \mathrm{kg})$ was observed in the root of the $K$. senegalensis planted in the EFKHS growth medium while the lowest root accumulation of $3.30 \pm 1.04 \mathrm{mg} / \mathrm{kg}$ was observed in the control (Fig 6).One-way ANOVA shows that there is significant difference between the $\mathrm{Zn}$ levels in the roots of the Khayasenegalensis obtained from irrigation with tannery effluent, borehole water and control at $P<0.05$. The Post Hoc Tukey test however, revealed that the $\mathrm{Zn}$ levels in the root of Khayasenegalensis from the tannery effluent irrigated medium is significantly higher than those obtained from the borehole water irrigated soil and control. Also, the root levels of $\mathrm{Zn}$ obtained from irrigation with borehole water is significantly higher than control. This results is consistent with the findings of (He et al., 2020) and (Steliga and Kluk, 2020)who noted that $\mathrm{Zn}$ mainly accumulated in the roots of Ricinuscommunis and Festucaarundinacea respectively(Yang et al., 2020) noted a high concentration of zinc in the roots of salix clones under flooded conditions.

\begin{tabular}{|c|c|}
\hline 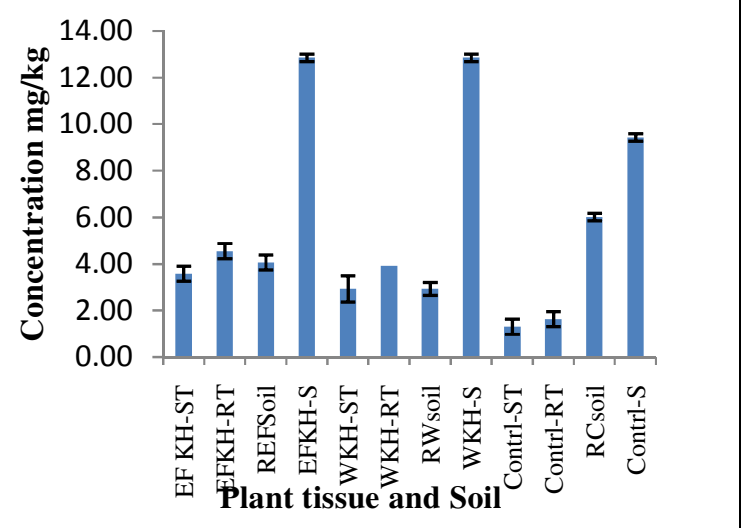 & I 60.00 - \\
\hline $\begin{array}{l}\text { Fig } 1 \text { : Concentration of Cadmium in tissues and Soil of } \\
\text { Khayasenegalensis }\end{array}$ & $\begin{array}{l}\text { Fig 2. : Concentration of Chromium in tissues and Soil of } \\
\text { Khayasenegalensis }\end{array}$ \\
\hline
\end{tabular}



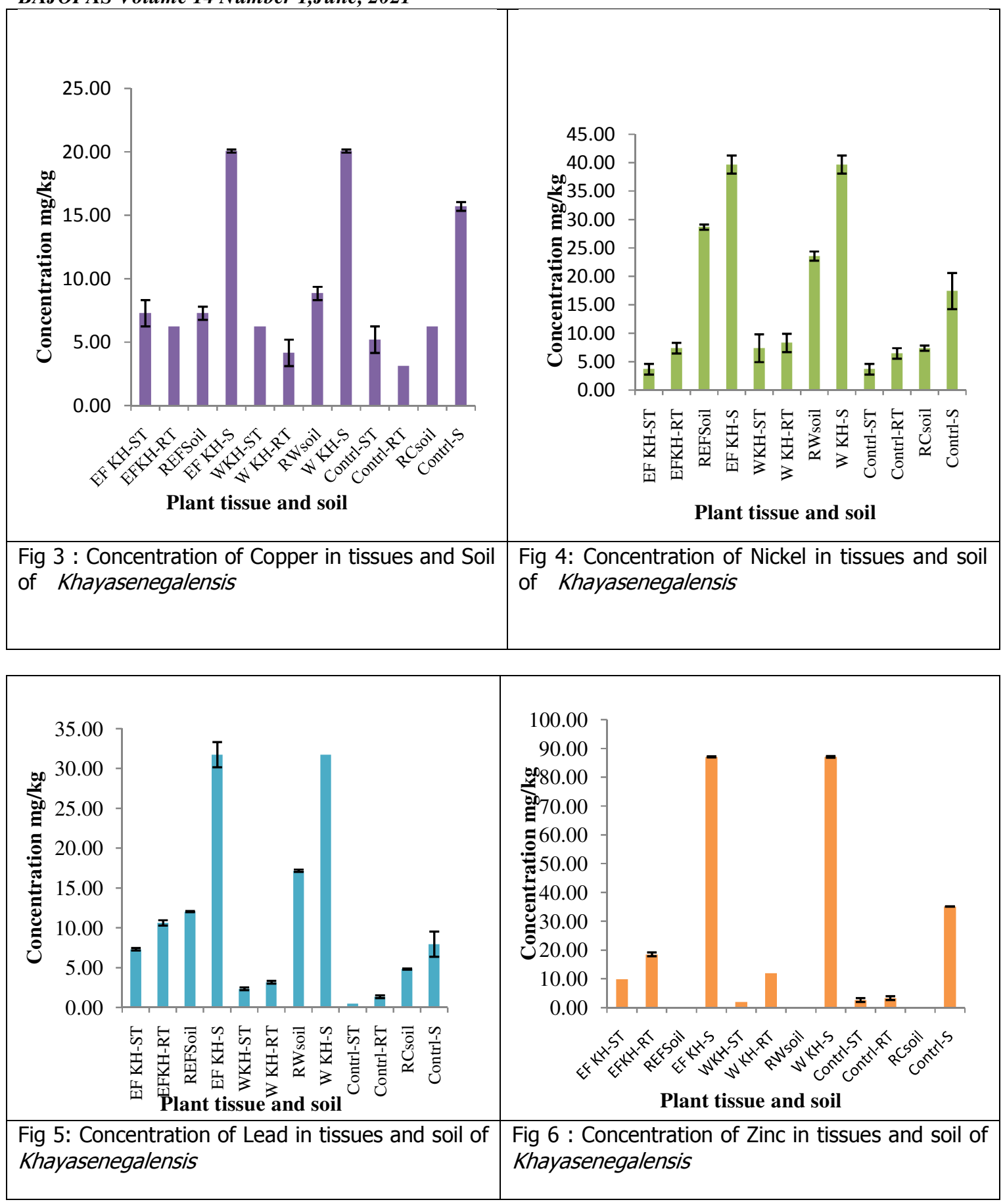

Translocation and Bioconcentration Factor The ability of phytoremediation has commonly been characterized by a Translocation Factor, TF which is defined as the ratio of the metal concentration in the shoots to that in the roots. Translocation factor (TF) was calculated using the formula(Sharma et al., 2021;Madanan et al., 2021)

Translocation

Factor

$=\frac{\text { Metal concentration in shoot of plant }(\mathrm{mg} / \mathrm{kg})}{\text { Metal }}$

(TF)
Phytoextraction as a process depends on successful heavy metal removal by the shoots. Plants with TF values $>1$ are classified as highefficiency plants for metal translocation from the roots to shoots. The results in this study showed that Khayasenegalensis had concentrations of metals showing TF values of $(1.17,1.50$ and 1.67) for $\mathrm{Cd}$ and (1.60, 1.00 and 1.00) for $\mathrm{Cu}$ which are all greater than one in growth media irrigated with tannery waste water, borehole water (ground water) and control respectively. 
BAJOPAS Volume 14 Number 1,June, 2021

However, for $\mathrm{Cd}(0.79,0.75$ and 0.80$), \mathrm{Cr}(0.82$, 0.64 and 1.00$), \mathrm{Ni}(0.50,0.89$ and 0.57$), \mathrm{Pb}$ $(0.69,0.74$ and 0.38$)$ and $\mathrm{Zn}(0.54,0.17$ and 0.80 ) concentrations in the tissues of the same plant show values of TF $<1$ in growth media irrigated with tannery waste water, borehole water and control respectively (Table 1 ). This is an indication that this plant could be regarded as an efficient plant for translocation of $\mathrm{Cu}$ from the roots to the shoots.

Table 1:Translocation and Bioconcentration for Khayasenegalensis

\begin{tabular}{lccc|ccc}
\hline TF & & & & BCF & & \\
\hline & EFKHS & WKHS & CONTROL & EFKHS & WKHS & CONTROL \\
\hline $\mathbf{C d}$ & 0.79 & 0.75 & 0.8 & 0.71 & 0.51 & 0.52 \\
$\mathbf{C r}$ & 0.82 & 0.64 & 1 & 0.62 & 0.48 & 0.49 \\
$\mathbf{C u}$ & 1.17 & 1.5 & 1.67 & 0.78 & 0.67 & 0.6 \\
$\mathbf{N i}$ & 0.5 & 0.89 & 0.57 & 0.42 & 0.47 & 0.37 \\
$\mathbf{P b}$ & 0.56 & 0.17 & 0.23 & 0.27 & 0.18 & 0.21 \\
$\mathbf{Z n}$ & 0.33 & 0.16 & 0.17 & 0.41 & 0.2 & 0.11 \\
\hline
\end{tabular}

Ability of a plant to accumulate metals from contaminated soils was evaluated by the Bioconcentration factor (BCF) using the formula (Madanan et al., 2021).

Bioconcentration factor (BCF) =

Average metal conc.in the whole plant $(\mathrm{mg} / \mathrm{kg})$

Metal conc.in soil (mg/kg)

This study assumed that plants with BCF values $>1$ are accumulators, while plants with BCF values less than 1 are excluders. The results in this study showed that Khayasenegalensis irrigated with tannery effluent, borehole water and control had BCF values $<1$ for the elements, $\mathrm{Cd}, \mathrm{Cr}, \mathrm{Ni}, \mathrm{Pb}$ and $\mathrm{Zn}$ indicating that the plant has the potential to be used as excluders (Phytostabilization). This property may be employed in phytostabilization where it is necessary to maintain the metals below the ground.

\section{CONCLUSION}

The study was able to reveal Khayasenegalensis as anaccumulator of $\mathrm{Cu}$ and is recommended for phytoextraction of this metal. Furthermore, the study revealed the potentials of this plant to be used as excluders of $\mathrm{Cd}, \mathrm{Cr}, \mathrm{Ni}, \mathrm{Pb}$ and $\mathrm{Zn}$. The

\section{REFERENCES}

Ali, H. M., Siddiqui, M. H., Khamis, M. H., Hassan, F. A., Salem, M. Z. M., \& ElMahrouk, E. S. M. (2013). Performance of forest tree Khaya senegalensis (Desr.) A. Juss. under sewage effluent irrigation. Ecological Engineering, 61, 117-126.

https://doi.org/10.1016/j.ecoleng.2013. 09.051

Amir, W., Farid, M., Farid, S., Zubair, M., Alharby, H. F., Bamagoos, A. A., Rizwan, M., Raza, N., Rehman, K., \& Ali, S. elevated concentration of these metals in its roots and low translocation to above ground parts show suitability for phytostabilization of these metals. Therefore, planting Khayasenegalensis in soils polluted with these metals as a result of contamination from tannery waste water can be an ideal option for phytostabilization. This will checkmate soil polluted with toxic elements as a result of pollution from tannery waste water.

Author's contributions: Zakari Abdullahi conducted the research while Prof A.A Audu supervised the research.

\section{Conflict of Interest}

The authors declare that the research was conducted in the absence of any commercial or financial relationships that could be construed as a potential conflict of interest. The authors declare that there is no conflict of interests regarding the publication of this paper.

\section{Acknowledgement}

The authors wish to acknowledge the financial support from Bayero University, Kano, Nigeria through the Directorate of research, innovation and partnerships research grant (BUK/DRIP/RG/2017/0063).

(2020). Chemosphere Accumulation potential and tolerance response of Typha latifolia $L$. under citric acid assisted phytoextraction of lead and mercury. 257. https://doi.org/10.1016/j.chemosphere. 2020.127247

Cuske, M., Karczewska, A., Gałka, B., \& Dradrach, A. (2016). Some adverse effects of soil amendment with organic Materials-The case of soils polluted by copper industry phytostabilized with red fescue. International Journal of 
BAJOPAS Volume 14 Number 1,June, 2021 Phytoremediation, 18(8), 839-846. https://doi.org/10.1080/15226514.2016. 1146227

Eid, E. M., Galal, T. M., Shaltout, K. H., Elsheikh, M. A., Asaeda, T., Alatar, A. A., Alfarhan, A. H., Alharthi, A., Alshehri, A. M. A., Picó, Y., \& Barcelo, D. (2020). Science of the Total Environment Biomonitoring potential of the native aquatic plant Typha domingensis by predicting trace metals accumulation in the Egyptian Lake Burullus. 714(January).

https://doi.org/10.1016/j.scitotenv.2020 .136603

Elshamy, M. M., Heikal, Y. M., \& Bonanomi, G. (2019). Chemosphere Phytoremediation ef $\mathrm{fi}$ ciency of Portulaca oleracea $\mathrm{L}$. naturally growing in some industrial sites , Dakahlia District , Egypt. Chemosphere, 225, 678-687. https://doi.org/10.1016/j.chemosphere. 2019.03.099

Godwin, E., \& Oluwagbemiga, D. (2020). Search for autochthonous plants as accumulators and translocators in a toxic metal-polluted coal mine soil in. Scientific African, 10, e00630. https://doi.org/10.1016/j.sciaf.2020.e00 630

Gupta, N., Khan, D. K., \& Santra, S. C. (2008). An Assessment of Heavy Metal Contamination in Vegetables Grown in Wastewater-Irrigated Areas of Titagarh, West Bengal, India. 115-118. https://doi.org/10.1007/s00128-0079327-Z

He, C., Zhao, Y., Wang, F., Oh, K., Zhao, Z., Wu, C., Zhang, X., Chen, X., \& Liu, X. (2020). Phytoremediation of soil heavy metals ( $\mathrm{Cd}$ and $\mathrm{Zn}$ ) by castor seedlings: Tolerance, accumulation and subcellular distribution. Chemosphere, 252, 126471. https://doi.org/10.1016/j.chemosphere. 2020.126471

Ibrahim, N., \& El, G. (2020). Heliyon Phytoremediation uptake model of heavy metals ( $\mathrm{Pb}, \mathrm{Cd}$ and $\mathrm{Zn}$ ) in soil using Nerium oleander. Heliyon, 6(March), e04445. https://doi.org/10.1016/j.heliyon.2020.e 04445

Li, X., Geng, T., Shen, W., Zhang, J., \& Zhou, Y. (2021). Ecotoxicology and Environmental Safety Quantifying the influencing factors and multi-factor interactions affecting cadmium accumulation in limestone-derived agricultural soil using random forest (
RF) approach. Ecotoxicology and Environmental Safety, 209, 111773. https://doi.org/10.1016/j.ecoenv.2020.1 11773

Madanan, M. T., Shah, I. K., Varghese, G. K., \& Kaushal, R. K. (2021). Application of Aztec Marigold (Tagetes erecta L.) for phytoremediation of heavy metal polluted lateritic soil. Environmental Chemistry and Ecotoxicology, 3, 17-22. https://doi.org/10.1016/j.enceco.2020.1 0.007

Mohammed, M. I., \& Inuwa, Y. (2018). Assessment of metals pollution in some herbs from Kano metropolis. Bayero Journal of Pure and Applied Sciences, 10(1), 356. https://doi.org/10.4314/bajopas.v10i1.7 $1 s$.

Mohanty, M., \& Kumar Patra, H. (2020). Phytoassessment of in situ weed diversity for their chromium distribution pattern and accumulation indices of abundant weeds at South Kaliapani chromite mining area with their phytoremediation prospective. Ecotoxicology and Environmental Safety, 194(December 2019), 110399. https://doi.org/10.1016/j.ecoenv.2020.1 10399

Olajuyigbe, S. O., \& Aruwajoye, D. A. (2014). Phytoremediation of diesel oil contaminated soil using seedlings of two tropical hardwood species (Khaya senegalensis and Terminalia superba). International Journal of Scientific \& Engineering Research, 5(6), 1067-1078.

Purakayastha, T. J., Viswanath, T., Bhadraray, S., Chhonkar, P. K., Adhikari, P. P., \& Suribabu, K. (2008). Phytoextraction of zinc, copper, nickel and lead from a contaminated soil by different species of Brassica. International Journal of Phytoremediation, 10(1), 61-72. https://doi.org/10.1080/1522651070182 7077

Ravi, S., Karthik, C., Kadirvelu, K., Indra, P., Shanmugasundaram, T., \& Bruno, B. (2020). Understanding the molecular mechanisms for the enhanced phytoremediation of heavy metals through plant growth promoting rhizobacteria: A review. Journal of Environmental Management, 254(April 2019), 109779. https://doi.org/10.1016/j.jenvman.2019. 109779

Sharma, P., Tripathi, S., \& Chandra, R. (2021). Highly efficient phytoremediation 
BAJOPAS Volume 14 Number 1,June, 2021 potential of metal and metalloids from the pulp paper industry waste employing Eclipta alba (L) and Alternanthera philoxeroide (L): Biosorption and pollution reduction. Bioresource Technology, 319(August 2020), 124147. https://doi.org/10.1016/j.biortech.2020. 124147

Si, L., Zhang, J., Hussain, A., Qiao, Y., Zhou, J., \& Wang, X. (2021). Accumulation and translocation of food chain in soilmulberry (Morus alba L.)-silkworm (Bombyx mori) under single and combined stress of lead and cadmium. Ecotoxicology and Environmental Safety, 208, 111582. https://doi.org/10.1016/j.ecoenv.2020.1 11582

Sivakumar, P. (2016). Phytoremediation of Tannery Waste Polluted Soil using Hyptis suaveolens (Lamiaceae). International Journal of Pure \& Applied Bioscience, 4(1), 265-272. https://doi.org/10.18782/23207051.2223

Steliga, T., \& Kluk, D. (2020). Application of Festuca arundinacea in phytoremediation of soils contaminated with $\mathrm{Pb}, \mathrm{Ni}, \mathrm{Cd}$ and petroleum hydrocarbons. Ecotoxicology and Environmental Safety, 194(October 2019), 110409. https://doi.org/10.1016/j.ecoenv.2020.1 10409

Tanee, F.B.G and Amadi, N. (2016). Screening of Polyalthia longifolia and Aloe vera for their phytoextractability of heavy metals in tropical soil of the Niger Delta.Journal of Applied Science and Environmental Manage.20, 1: 141 - 147 (2016).

Tauheed, A. M., Mamman, M., Ahmed, A., Suleiman, M. M., \& Balogun, E. O. (2020). In vitro and in vivo antitrypanosomal efficacy of combination therapy of Anogeissus leiocarpus, Khaya senegalensis and potash. Journal of Ethnopharmacology, 258(January), 112805. https://doi.org/10.1016/j.jep.2020.1128 05

Ullah, F., Liqun, C., Coulter, J. A., Alam, S., Wu, J., Zhang, R., Wenjun, M., \& Farooq, M. (2021). Ecotoxicology and Environmental Safety Cadmium toxicity in plants: Impacts and remediation strategies. Ecotoxicology and Environmental Safety, 211, 111887. https://doi.org/10.1016/j.ecoenv.2020.1 11887

Wise, M., \& Mokokwe, G. (2020). Heliyon Accumulation of heavy metals and bacteriological indicators in spinach irrigated with further treated secondary wastewater. Heliyon, 6(October), e05241. https://doi.org/10.1016/j.heliyon.2020.e 05241

Yang, W., Zhao, F., Wang, Y., Ding, Z., Yang, X., \& Zhu, Z. (2020). Differences in uptake and accumulation of copper and zinc by Salix clones under flooded versus nonflooded conditions. Chemosphere, 241, 125059. https://doi.org/10.1016/j.chemosphere. 2019.125059

Zhang, Z., Wu, X., Tu, C., Huang, X., Zhang, J., Fang, H., Huo, H., \& Lin, C. (2020). Ecotoxicology and Environmental Safety Relationships between soil properties and the accumulation of heavy metals in different Brassica campestris $L$. growth stages in a Karst mountainous area. Ecotoxicology and Environmental Safety, 206(August), 111150. https://doi.org/10.1016/j.ecoenv.2020.1 11150 